Table 1 Clinical features of patients with or without clinical relapse

\begin{tabular}{lcc}
\hline & $\begin{array}{c}\text { Without clinical relapse } \\
(n=11)\end{array}$ & $\begin{array}{c}\text { With clinical relapse } \\
(n=9)\end{array}$ \\
\hline Age (y) & $75 \cdot 1(8 \cdot 3)$ & $75 \cdot 6(7 \cdot 6)$ \\
Sex ratio (M:F) & $1: 10$ & $4: 5$ \\
Diseases & $9 \mathrm{PMR}$ & $8 \mathrm{PMR}$ \\
& $2 \mathrm{GCA}$ & $1 \mathrm{GCA}$ \\
Disease duration (months) & $57 \cdot 8(51 \cdot 4)$ & $51 \cdot 4(43 \cdot 7)$ \\
Prednisone dose (mg/day) & & $16 \cdot 8(6)$ \\
Initial & $19 \cdot 7(8 \cdot 4)$ & $5(2 \cdot 1)$ \\
Before reduction & $3 \cdot 9(1 \cdot 9)$ & $2 \cdot 1(1 \cdot 4)$ \\
After reduction & $1 \cdot 8(1 \cdot 1)$ & \\
\hline
\end{tabular}

Values are mean (SD).

PMR = Polymyalgia rheumatica GCA $=$ giant cell arteritis.

Table 2 Results of laboratory tests in nine patients before prednisone reduction and at clinical relapse

\begin{tabular}{llll}
\hline & $\begin{array}{l}\text { Before prednisone } \\
\text { reduction }\end{array}$ & $\begin{array}{l}\text { At clinical } \\
\text { relapse }\end{array}$ & $\begin{array}{l}\text { Wilcoxon test } \\
\text { p value }\end{array}$ \\
\hline ESR $(\mathrm{mm} / 1 \mathrm{st} \mathrm{h})$ & $20(14)$ & $25(16)$ & $0 \cdot 19$ \\
CRP $(\mathrm{mg} / \mathrm{l})$ & $9 \cdot 8(2 \cdot 3)$ & $15 \cdot 3(12 \cdot 7)$ & $0 \cdot 18$ \\
Orosomucoid $(\mathrm{g} / \mathrm{l})$ & $0 \cdot 85(0 \cdot 21)$ & $0 \cdot 91(0 \cdot 24)$ & $0 \cdot 24$ \\
Haptoglobin $(\mathrm{g} / \mathrm{l})$ & $1 \cdot 41(0 \cdot 63)$ & $1 \cdot 64(0 \cdot 92)$ & $0 \cdot 10$ \\
Fibrinogen $(\mathrm{g} / \mathrm{l})$ & $4(0 \cdot 8)$ & $4 \cdot 5(1 \cdot 4)$ & $0 \cdot 29$ \\
IL-6 $(\mathrm{pg} / \mathrm{ml})$ & $4(12)$ & $14(23)$ & $0 \cdot 04$ \\
\hline
\end{tabular}

Values are mean (SD).

$\mathrm{ESR}=$ Erythrocyte sedimentation rate; $\mathrm{CRP}=\mathrm{C}$ reactive protein IL- $6=$ interleukin -6

reduction of their prednisone dose (data not shown). In the nine patients with clinical relapse, ESR, CRP, orosomucoid, haptoglobin, and fibrinogen each showed a nonsignificant increase at clinical relapse compared with the values observed before the reduction of prednisone, while IL- 6 values were significantly increased $(p=0.04)$ (table 2 ). Among the same nine patients, only two had an ESR $\geq 30 \mathrm{~mm} / 1 \mathrm{st} \mathrm{h}$, and two had CRP concentrations $\geq 10 \mathrm{mg} / \mathrm{l}$, while four had IL-6 concentrations $\geq 5 \mathrm{pg} / \mathrm{ml}$ at clinical relapse. In all patients experiencing clinical relapse, symptoms were controlled after their dose of prednisone was increased again. Among the three patients with giant cell arteritis, two had no relapse and did not have increased concentrations of IL- 6 . No unexpected increase in IL-6 concentration occurred in patients without relapse: the IL-6 value in this group of patients was 7 (20) $\mathrm{pg} / \mathrm{ml}$ before reduction of the dose of prednisone, and 5 (10) $\mathrm{pg} / \mathrm{ml}$ one month afterwards.

These preliminary data have demonstrated an increase in the plasma concentration of IL-6 during clinical relapses of polymyalgia rheumatica and giant cell arteritis, while ESR, CRP, haptoglobin, orosomucoid, and fibrinogen showed minimal variations. Additional studies are required to determine the further potential usefulness of IL-6 in the management of polymyalgia rheumatica and giant cell arteritis.

D CAPLANNE

J-M LE PARC
Department of Rheumatology, Ambroise Paré Hospital,
René Descartes University, 94104 Boulogne Cedex, France

J-A ALEXANDRE

Department of Clinical Chemistry

Correspondence to: D Caplanne.

1 Kyle V, Hazleman B L. Stopping steroids in polymyalgia and giant cell arteritis. $B M \mathcal{F}$ polymyalgia and

2 Ellis M E, Ralston $\mathrm{S}$. The ESR in the diagnosis and management of the polymyalgia and management of the polymyalgia Rheum Dis 1983; 42: 168-70.

3 Mallya R K, Hind C R K, Berry H, Pepys M B. Serum c-reactive protein in polymyalgia Serum c-reactive protein in polymyalgia
rheumatica. Arthritis Rheum 1985; 28: $383-7$.

4 Kyle V, Cawston T E, Hazleman B L. Erythrocyte sedimentation rate and $\mathrm{C}$ reactive protein in the assessment of polymyalgia rheumatica/giant cell arteritis on presentation and during follow up. Ann Rheum Dis 1989; 48: $667-71$.

5 Dasgupta B, Panayi G S. Interleukin-6 in serum of patients with polymyalgia rheumatica and giant cell arteritis. Br $\mathcal{F}$ Rheumatol 1990; 29: 456-8.

6 Roche N E, Fulbright J W, Wagner A D, Hunder G G, Goronzy J J, Weyand C M. Correlation of interleukin- 6 production and disease activity in polymyalgia rheumatica and giant cell arteritis. Arthritis Rheum 1993; 36: 1286-94.

Bird H A, Esselinckx W, Dixon A S T J, Mowat A G, Wood H N. An evaluation criteria for polymyalgia rheumatica. Ann Rheum Dis 1979; 38: 434-9.

8 Hunder G G, Bloch D A, Michel B A, et al. The American College of Rheumatology 1990 criteria for the classification of giant cell arteritis. Arthritis Rheum 1990; 33: 1122-8.

\section{Role of androgens in the aetiology of rheumatoid arthritis}

It is likely that the gender difference in the occurrence of rheumatoid arthritis (RA) can be explained, at least in part, by the effects of sex hormones, with both increased concentrations of prolactin and decreased concentrations of androgen being implicated. ${ }^{1}$ Androgen concentrations also appear to be regulated by genes encoded within the HLA region, with lower concentrations reported among men who are HLA-B15 positive $^{2}$ and women who are HLA-DR4 positive. $^{3}$ Other data supporting the hypothesis that androgen concentrations influence the onset of RA are based on the observation that siblings of RA probands are more likely to be female.
Number of sons and daughters among women with $R A$, according to mothers' $H L A-D R 4$ status

\begin{tabular}{lll}
\hline $\begin{array}{l}\text { Mothers' HLA- } \\
\text { DR status }\end{array}$ & $\begin{array}{l}\text { Number of } \\
\text { daughters }\end{array}$ & $\begin{array}{l}\text { Number of } \\
\text { sons }\end{array}$ \\
\hline DR4+ $(\mathrm{n}=159)$ & $84(53 \%)$ & $75(47 \%)$ \\
DR4- $(\mathrm{n}=43)$ & $15(35 \%)$ & $28(65 \%)$ \\
\hline
\end{tabular}

It is feasible that the sex ratio of siblings may be associated with the development of autoimmune disease, as hormone concentrations are believed to affect the sex of offspring. ${ }^{5}$ Therefore, parents with low testosterone concentrations may be more likely to have female children, with these children being at an increased risk of developing RA because of their inherited tendency for low testosterone concentrations.

If this hypothesis were true, it would also be expected that women with RA would themselves be more likely to have daughters instead of sons. Indeed, Deighton et al have previously reported such a finding, ${ }^{3}$ though numbers were small (16 daughters and seven sons). We have therefore investigated this relationship among a larger group of 94 women with RA. These women had provided pregnancy information and undergone HLADR typing for the purpose of another study (submitted for publication). The hypothesis was that if women with RA experience reduced concentrations of androgens, they might be expected to have an excess of daughters. Given that androgen concentrations may be partially regulated by HLADR4 status, the analysis was conducted separately for HLA-DR4 positive and negative women.

Overall, the 94 women had 202 children: 99 girls and 103 boys. The observed proportion of children that were daughters $(0 \cdot 49)$ was the same as that expected. When considered separately by HLA-DR status, however, there was an excess of sons among the HLA-DR4 negative mothers, and an excess of daughters among the HLA-DR4 positive mothers (table). The odds ratio associated with being HLA-DR4 positive and bearing a daughter was $2 \cdot 1$ ( $95 \%$ confidence interval $1 \cdot 1$ to $4 \cdot 2$ ). This therefore does appear to provide tentative evidence of a link between HLA-DR status and the gender of offspring, supporting a role for androgens in the aetiology of RA. However, these observations need to be repeated in other populations.

PAUL BRENNAN ALAN SILMAN ARC Epidemiology Research Unit ARC Epidemiology Research Unit
Anchity of Manchester Medical School University of Manchester Medical School
Manchester M13 9PT, United Kingdom Manchester M13 9PT, United Kingdom

Brennan P, Silman A. Why the gender difference in susceptibility to rheumato arthritis. Arthritis Rheum 1995; 54: 694-5.

2 Ollier W, Spector T, Silman A, et al. Are certain HLA haplotypes responsible for low 7: $139-43$.

3 Deighton C M, Watson M, Walker D J. RA sex ratios, HLA-DR, and testosterone. Ann Rheum Dis 1993; 52: 244

4 James W H. Sex ratio and hormones in HLA related rheumatic diseases. Ann Rheum Dis 1991; 50: 401-4.

5 James W $\mathrm{H}$. The hypothesized hormonal control of mammalian sex ratio at birth. $f$ Theor Biol 1992; 155: 121-8. 